\title{
CHARACTERIZATION AND POTENCY OF STICHOPUS HERMANNI ETHANOL EXTRACT ON ORAL WOUND HEALING
}

\section{Rima Parwati Sari*, Stevanus Chandra Sugiarto Budijono*}

* Departement of Oral Biology, Faculty of Dentistry, Universitas Hang Tuah

Correspondence : Rima Parwati Sari, Departement of Oral Biology, Faculty of Dentistry, Universitas Hang Tuah

Email : rima.parwatisari@hangtuah.ac.id, stv vip@yahoo.com

\begin{tabular}{c}
\hline Keywords: \\
Glycosaminoglycans, \\
Stichopus hermanni, \\
traumatic ulcer
\end{tabular}

\section{ABSTRACT}

Background: Stichopus hermanni contains protein, glycosaminoglycans and EPA-DHA, which accelerate oral wound healing. Ethanol is solvent with universal nature and frequently used in the extraction. This study aims to know the characterization and potency of Stichopus hermanni in oral wound healing. Methods: Stichopus hermanni was dried by freeze-dry method and extracted using ethanol solvent. Characterization was examined the levels of protein, glycosaminoglycans and EPA-DHA. In vivo, male wistar rats made traumatic ulcer at the lower labial mucosa by using thermal burn. Thirty-two rats are divided into four groups $(n=8)$, negative control group $(K)$, positive control group $(\mathrm{AH})$ was given hyaluronic acid gel $0.2 \%$, and treatment groups were given Stichopus hermanni 60\%-80\% (SH60-SH80) gel. The ulcer formed was given gel for four days. The rat's labial mucosa was measured. The difference between the first and fourth day is tabulated. Data were analyzed by Anova and Tukey-HSD tests.

Results: The result of Spectrophotometry show the contents of protein (19.39), glycosaminoglycans (2.79-3.98). The result of in vivo showed a significant difference in ANOVA test $(\mathrm{K}=1.07 ; \mathrm{AH}=1.27 ; \mathrm{SH} 60=1.89 ; \mathrm{SH} 80=1.66)$. In the Tukey-HSD test, the $\mathrm{SH} 60$ group shows a significant difference between $\mathrm{K}$ and $\mathrm{AH}$ groups.

Conclusion: Stichopus hermanni ethanol extract gel contain protein and Glycosaminoglycans and potency for oral wound healing.

\section{INTRODUCTION}

Sea cucumber is one of the marine commodities with high selling power and is even considered the superior export commodity of Indonesian fishers. Despite their unattractive form, sea cucumbers contain a high amount of protein.
This causes the increased demand for sea cucumbers along with society's increased awareness of the importance of healthy food consumption. ${ }^{1}$

In addition to consumptive needs, sea cucumbers in fact also became the more advanced research subject for primary medication material. 
Some researches stated that sea cucumber has pharmacological effects, such as anti-inflammation and anti-bacteria and serves as anti-oxidant. ${ }^{2}$ Among many kinds of sea cucumbers (Echinodermata), Stichopus hermanni has more glycosaminoglycans and less saponin amount than Holothuriae scabra does. Other than that, unsaturated fatty acids, such as arachidonic acid (AA), eicosapentaenoic acid (EPA) and docosahexaenoic acid (DHA) are found much more in Sticophus hermanni. ${ }^{3}$

In the previous research, either in vitro or in vivo, sea cucumber is proven non-toxic and may stimulate FGF2 on rats that induced traumatic ulcer. ${ }^{4}$ It is because sea cucumbers contain glycosaminoglycan (GAGs) and omega-3, which are potential in the process of tissue remodelling. The component of glycosaminoglycans is highly required in the process of wound healing. Those are related since the components of glycosaminoglycan, such as hyaluronic acid, dermatan sulphate, chondroitin sulphate, heparin and heparin sulphate, are very required in the wound healing. ${ }^{5}$ Hyaluronic acid is important in the process of initial inflammation since it may trigger the increase of inflammation cells infiltration and products of cytokine pro-inflammation, and is important in controlling angiogenesis during tissue repairing which functions to protect granulation tissue from damages due to ROS (Reactive Oxygen Species) ${ }^{6}$

Another content of sea cucumbers which is beneficial is omega-3 which consists of DHA (docosahexaenoic acid) and EPA (eicosapentaenoic acid). EPA and DHA are key mediators in controlling the inflammation process upon the process of wound healing. ${ }^{7}$ In a research from McDaniel et al., 8 it is stated that EPA and DHA may cause an increase of IL-1 which governs fibroblast proliferation and collagen synthesis so that it will produce healthy collagen. The benefits are minimizing the scarring formation and increasing the power of connective tissue. IL-1 also contributes in increasing keratinocyte growth for reepithelization and in stimulating angiogenesis. ${ }^{8}$

GAGs are natural substance found in chemical compositions of connective tissue and soft tissue existing in human and animal. This substance is polar in nature because it is a complex heterogenous polysaccharide. ${ }^{9}$ Another content of sea cucumbers which is beneficial for sea cucumbers is omega-3 which consists of DHA and EPA. Due to the various contents of sea cucumbers with their polar and semi-polar natures, extraction method using ethanol solvent is therefore required to obtain a good extraction result with a high amount of GAGs, DHA and EPA. Ethanol solvent produces more sea cucumber extraction compared to nonpolar solvents. ${ }^{10}$ It is because most of sea cucumber contents are protein and carbohydrate with high polarity. In addition, it is also due to the sample that is used is a marine invertebrate from the ocean, which contains a high amount of salt particles. Therefore, compared to the fractions of ethyl-acetate and $n$-hexane, the percentage of water fraction is much higher because the salt only dissolves into water fraction. ${ }^{11}$

Production of preparation material form is a key to maximize the wound-healing effect of sea cucumber. The hydrogel is an ideal biopolymer preparation form for the wound healing medication. This preparation form has low surface tension, high molecular and oxygen permeability, is a good moisturizer and has mechanical nature which resembles the physiology of soft tissue. Hydrogel preparation occurs due to the rising process of the polymer as well as its active material, its mechanical nature (hardness, cohesion, and adhesivity) and bio adhesivity nature that needs to be further researched to achieve the maximum result. 
Besides, one of the hydrogel's characters is if polymer concentration increases, the formulation of water viscosity and absorption capacity also improves. ${ }^{12}$

\section{METHODS}

\section{Stichopus hermanni extraction}

Stichopus hermanni observed in this study were collected from the coastal areas of Bontang, East Kalimantan, with the criteria of weight and length achieved was 400-500 grams/head. Stichopus hermanni were kept in labelled plastic bags before they were stored in a freezer at $-80^{\circ} \mathrm{C}$. The animals were thawed from deep freezer, thoroughly washed with distilled water, cut up longitudinally along the bodyline to remove the visceral organs. The remaining body walls were dried on blotting papers before being homogenized to a fine texture. The whole extract was prepared in which 50 grams of the animal were placed in 250 $\mathrm{ml}$ Erlenmeyer flask to which $100 \mathrm{ml}$ of each of distilled water in the ratio of 1:2 was added. In the next phase, the freeze-drying method was carried out to obtain dried preparation of the sea cucumber. The freeze-drying result was soaked or macerated with ethanol solvent $96 \%$ (polar) for 24 hours, and the filtrate was filtered and retained. This maceration process was conducted three times and then was evaporated. ${ }^{10,11}$

\section{Characterization of Sea Cucumber}

Analysis of total protein concentration

One gram of the refined material was placed in the Kjeldahl flask. If the protein content of the material is high, the material used is less than 1 gram. Then, add 7.5 grams of K2S2O4 and $0.35 \mathrm{~g}$ $\mathrm{HgO}$ (beware of these toxic substances) and finally add $15 \mathrm{ml}$ of thick $\mathrm{H}_{2} \mathrm{SO}_{4}$. Heat all materials in Kjeldahl flask in the acid case until they stop releasing smoke. Continue the heating with big fire until it boils, and the liquid becomes clear. Continue the additional heating for approximately one hour. Afterwards, turn off the heater fire and let the material cold. Then, add $100 \mathrm{ml}$ of distilled water into the Kjeldahl flask that that has been cooled in iced water and some $\mathrm{Zn}$ plates. $15 \mathrm{ml}$ of $\mathrm{K}_{2} \mathrm{~S}$ solution of $4 \%$ was also added (in the water) and, finally, gradually add $50 \mathrm{ml}$ of $\mathrm{NaOH}$ solution of $50 \%$ that was already cooled into the refrigerator. Put Kjeldahl flask immediately in the distillation equipment. Afterwards, slowly heat Kjeldahl flask until two liquid layers are mixed up, and then quickly heat it until it boils. This distillation retained in the Erlenmeyer flask that was filled up with $50 \mathrm{ml}$ of a standard solvent of $\mathrm{HCl}(0.1 \mathrm{~N})$ and five drops of red methyl indicator. Conduct the distillation until the retained distillation is $75 \mathrm{ml}$. Titrate the distillation that obtained with standard $\mathrm{NaOH}(0.1 \mathrm{~N})$ until the colour becomes yellow. Please also make a blank solution by replacing the material with the distilled water. Conduct the instruction, distillation, and titration according to the sample material. ${ }^{13}$

Calculation of $\% \mathrm{~N}:{ }^{13}$

$$
\begin{gathered}
\% \mathrm{~N}=\frac{(\mathrm{ml} \mathrm{NaOH} \text { blank }-\mathrm{ml} \mathrm{NaOH} \text { sample })}{\mathrm{G} \text { sample } \times 1000} \times 100 \times 14.008 \\
\% \text { protein }=\% \mathrm{~N} \times 6.25
\end{gathered}
$$

Analysis of glycosaminoglycan concentration under spectrophotometry method using sulphate GAGs assay

Analysis of glycosaminoglycan concentration was measured under the spectrophotometry method using sulphate GAGs assay, which refers to Jong et al. modified by Zhou et al. . ${ }^{14}$ Methylene blue stock solution was made by dissolving $25 \mathrm{mg}$ of methylene blue into $50 \mathrm{~mL}$ of aqua bidestilata. Five $\mathrm{mL}$ of the stock solution is diluted with aqua bidestilata until it reached the volume of $30 \mathrm{~mL}$. The solution was then used as the reagent in testing the glycosaminoglycan concentration. The sample 
solution was made by mixing $0.25 \mathrm{~mL}$ of glycosaminoglycan solution into $0.25 \mathrm{~mL}$ of aqua bidestilata and added with $2.5 \mathrm{~mL}$ of methylene blue. The sample solution was maintained for 5 minutes to 2 hours, and its absorbancy measured. The absorbance measurement was carried out using a spectrophotometer in the wavelength of 540 $\mathrm{nm}$ for hyaluronic acid, chondroitin sulphate, and dermatan sulphate, and $610 \mathrm{~nm}$ for hepharine sulphate. The standard curve was obtained by measuring the standard absorbent value of Hyaluronic acid (53747, sigma@aldrich $\left.{ }^{\circledR}\right)$, chondroitine sulphate (C 4384, sigma@aldrich ${ }^{\circledR}$ ), dermatan sulphate (D 3788, sigma@aldrich ${ }^{\circledR}$ ) and hepharine sulphate $\left(\mathrm{H} 7640\right.$, sigma@aldrich $\left.{ }^{\circledR}\right)$. The stock solution of the standard solution was made by dissolving 0.2 gram of the standard solution in distilled water until it reached the volume of 100 $\mathrm{mL} .14,15$ The standard test solution was obtained by diluting the stock solution of the standard solution until it generated a solution with a concentration of $200,600,1000$, and 1400 ppm, respectively. This research was performed at ULP, Pharmaceutical Laboratory of the Airlangga University of Surabaya.

Analysis on concentrations of AA, EPA, and DHA under spectrophotometry method

Two $\mathrm{ml}$ of the sample was put into the $50 \mathrm{ml}$ measuring flask, added with $2 \mathrm{ml}$ of methanol and 1 gr of brick salt, and then vortexed for 1 minute. Then, n-hexane was added until it reached the precise sign, processed in an ultrasonic way for 15 minutes, and shaken. Subsequently, the mixture was divided into 2 phases. The upper phase was carefully taken with $4.0 \mathrm{ml}$ of it was put into derivatization tube, sprayed by nitrogen until stiff, turned into foam by adding $2 \mathrm{ml}$ of $\mathrm{NaOH}$ methanolate. The tube was then tightly closed, vortexed for a while, and then heated in the temperature of $90^{\circ} \mathrm{C}$ for 5 minutes and cooled down to room temperature afterward. After that, derivatization was conducted by adding $2 \mathrm{ml}$ of BF3 with the tube tightly closed and vortexed for a while, heated in $90^{\circ} \mathrm{C}$ temperature for 30 minutes, and then cooled down to room temperature. Four $\mathrm{ml}$ of n-hexane p.a then was added with volume pipet, vortexed for about 2 minutes, and then it is put aside until separated into 2 phases. The $n$-hexane (the upper layer) was taken as necessary to be analyzed using GC-MSD (injected volume of $1 \mathrm{ul}$ ). ${ }^{16}$

\section{Pre-clinical test to the experimental animals}

This was a true experimental research that used a completely randomized design (CRD). The parameter of this research is the largest TU diameter difference in labial mucosa of Wistar rat from the first day of ulcer formation until the day in which one of the samples healed. The 32 rats as the research samples, were randomly divided into four groups. The sample criteria are male Wistar rats with the age of 5 months and body weight of about 200-300 grams.17,18 Prior to treatment, the rats underwent a one-week adjustment to their environment, and their conditions maintained. Ethical clearance for this experimental study was conducted by the committee of the ethics team of Faculty of Dentistry, Universitas Hang Tuah, No. 030/KEPK/I/2013.

The tools used were container tubes for sea cucumbers, cages for Wistar rats, wight scales for Wistar rats, cement stopper, cotton pellet, anatomy pincers, plastic filling instrument, and digital calliper. The materials used were water extract of sea cucumbers, extracted ethanol of sea cucumbers, sodium carboxymethylcellulose ( $\mathrm{NaCMC}$ ), dimethyl sulfoxide (DMSO) $5 \%$, sterile distilled water (aquadest) solution, (certain mark) hyaluronic acid (AH) $0.2 \%$ and ether solution. This research used 
extracted ethanol of sea cucumber with concentrations of $60 \%$ and $80 \%$.

The research was conducted at the Oral Biology Laboratory of Dentistry Faculty of Hang Tuah University Surabaya for the making of sea cucumber extracted gel and the treatment on the tested animals. The research procedure of this preclinical test was started by the acclimatization of the tested animal for one week within the laboratory environment. Prior to the treatment, Wistar rats were given through inhalation with ether solution. Afterwards, the ulcer was made by putting a heated cement stopper $(\varnothing 2 \mathrm{~mm})$ at the center of lower labial mucosae of all rats for 1 second. ${ }^{19}$ On the second day, the observation was conducted on whether or not the ulcer has been formed. If ulcer has been formed, it would be dried with sterile cotton pellet, and ulcer diameter was first measured using a digital calliper.

The measurement is done by pulling the labial mucosa on the left and right lip mucosa. Furthermore, the ulcer that looks is measured by using a digital calliper and the result documented. Afterwards, topical application of sterile distilled water was given to negative control group, topical application of $\mathrm{AH}$ gel of $0.2 \%$ was given in positive control group, topical application of sea cucumber ethanol extract $60 \%$ gel (SH60) was given in treatment group 1, and topical application of sea cucumber ethanol extract $80 \%$ gel (SH80) was given treatment group 2 by using a plastic filling instrument of $0.02 \mathrm{ml}$ and then spreaded up as well as maintained for a moment ( \pm 1 minute) to let the gel to be absorbed. Medicine application in topical manner was carried out once a day until one of the samples from test group was healed. Measurement and recording of ulcer diameter was also carried out every day until one of the samples from the test was healed. Data tabulation is done by calculating the difference in diameter of the ulcer on day 6 and day 2 (the first day the ulcer occurs).

The data of the average TU diameter difference in each group was tabulated. Statistics calculation was then performed for the data by conducting prior normality and homogeneity tests. If the data was normally distributed and had homogenous variance, it would be followed by a hypothetical test using parametric statistics of oneway ANOVA and TUKEY HSD.

\section{RESULTS}

Upon characterization at ULP FF, it showed the existence of results difference of active contents. See Table 1.

Table 1. Characterization of contents of protein, GAGs and EPA-DHA of extracted ethanol of Stichopus hermanni

\begin{tabular}{lr}
\hline Active Content & $(\%)$ \\
\hline Protein & 19.39 \\
Hyaluronic acid & 3.98 \\
Chondroitine Sulphate & 7.01 \\
Dermatan Sulphate & 2.36 \\
(Chondroitine sulphate B) & \\
Hepharin Sulphate & 2.79 \\
EPA & - \\
DHA & - \\
\hline \multicolumn{1}{c}{ After making a traumatic ulcer by placing a }
\end{tabular}
hot cement stopper, an ulcer is formed one day later. Measurements were made until the 6th day because in some mice, the healing had occurred, especially the healing occurred in the SH60 group. (Figure 1). Figure 2 showed the average TU in each group, which descriptively indicates that there are differences of TU diameter among $\mathrm{K}, \mathrm{AH}, \mathrm{SH} 60$ and SH80 groups. This descriptive statistical test result showed the average TU diameter by the deviation of day six minus day 2 in the group treated with extracted ethanol of sea cucumbers, either with concentrations of $60 \%$ or $80 \%$, which suggested higher results compared to $\mathrm{K}$ and $\mathrm{AH}$ groups. 


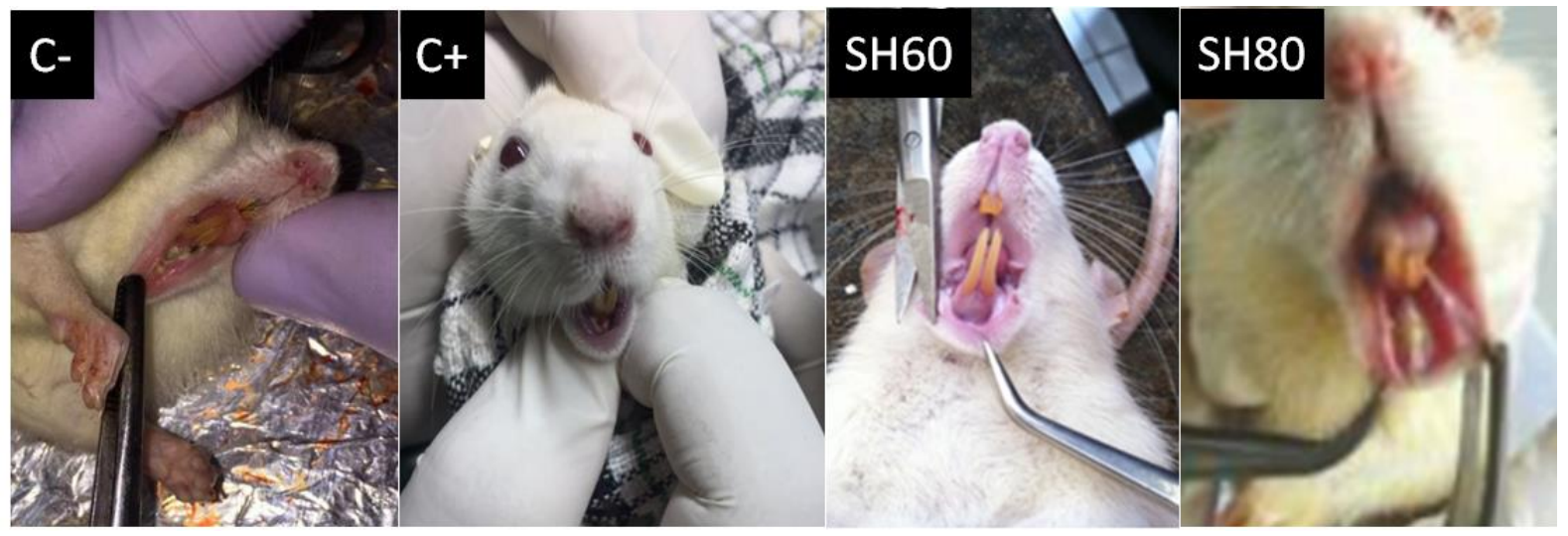

Figure 1. Image of ulcer formation on day 6

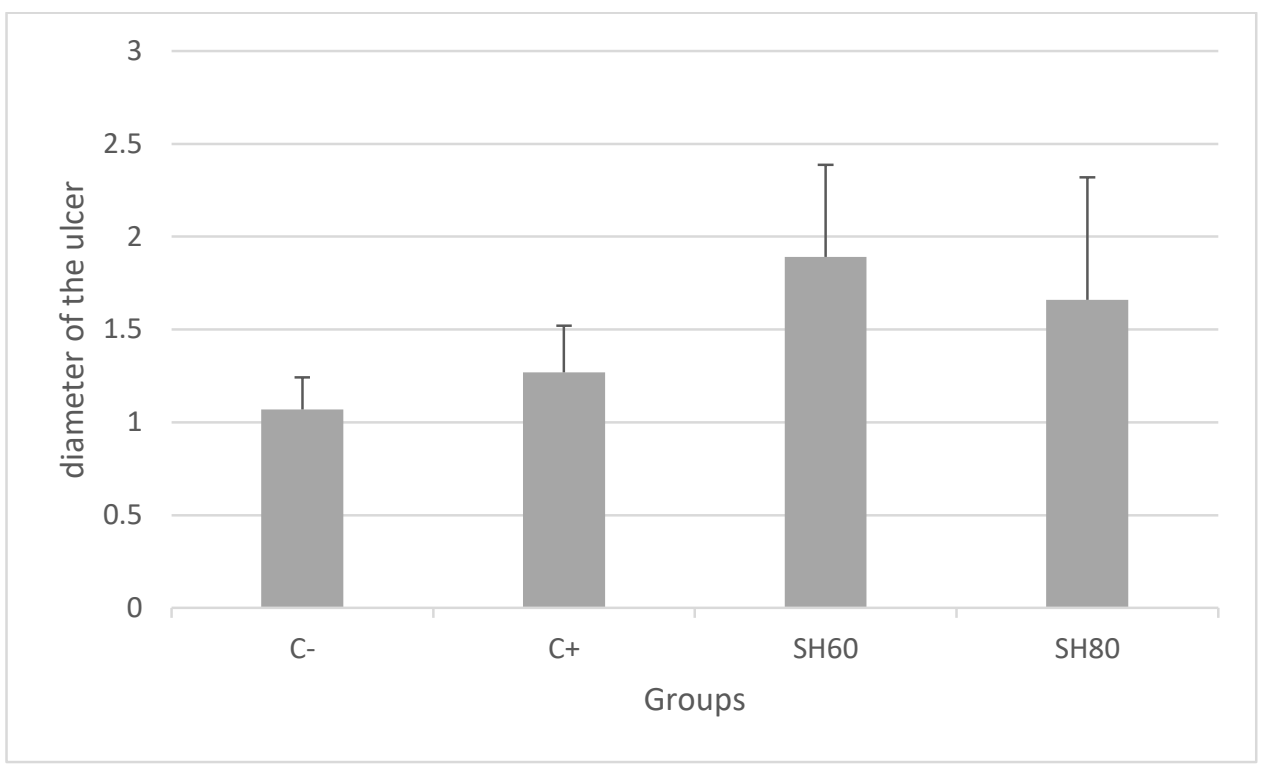

Figure 2. The mean diameter of the ulcer on the 5th-day post-induction of the traumatic ulcer due to the cement stopper being heated. (C- = negative control; $\mathrm{C}+=$ positive control; $\mathrm{SH} 60=$ Stichopus hermanni treatment $60 \%$; SH80 = Stichopus hermanni treatment $60 \%$ )

Shapiro-Wilk test result and Levene test showed that the data has normal and homogenous distribution and therefore ANOVA test can be followed afterwards. ANOVA test result showed a significant difference among the treatment groups $(p=0.001)$. Tukey-HSD results showed significant differences of diameter between $\mathrm{K}$ and $\mathrm{AH}$ groups compared to SH60 treatment group (extracted ethanol of sea cucumber $60 \%$ ) with $p<0.05$. The complete test results of Tukey-HSD were presented in Table 2.
Table2. Tukey HSD Test Results

\begin{tabular}{ccc}
\hline Group & & P-Value \\
\hline $\mathbf{K}$ & $\mathrm{AH}$ & .161 \\
\hline & $\mathrm{SH60}$ & $.002^{*}$ \\
\hline & $\mathrm{SH} 80$ & .130 \\
\hline AH & $\mathrm{SH60}$ & $.015^{*}$ \\
\hline \multirow{2}{*}{ SH60 } & SH80 & .442 \\
\hline
\end{tabular}

\section{DISCUSSION}

Ethanol is a polar compound considered a universal solvent that can dissolve polar compounds and a few non-polar compounds. 
Ethanol is generally able to extract components from glycoside group and a few from volatile oil. ${ }^{20}$ Ethanol with chemical formula of $\left(\mathrm{CH}_{3}-\mathrm{CH}_{2}-\mathrm{OH}\right)$ has the boiling point of $79^{\circ} \mathrm{C}$. The solubility of a dissolved compound within an organic solvent is affected by a total number of double joints and length of the carbon chain. The more number of double joints, the higher its solubility will be. On the contrary, the shorter chain results in the lower solubility of a compound. ${ }^{21}$

Protein and glycosaminoglycan are chemical compounds with long chains and polar nature and thus this compound dissolves upon maceration with ethanol. In characterization with spectrophotometry tool, it is shown that sea cucumbers contain quite a large amount of protein and GAGs with various levels. ${ }^{14}$

According to Bordbar et al. ${ }^{3}$, Stichopus hermanni contains quite high EPA and DHA. However, in this extracted ethanol of sea cucumber, these were not found. Despite being known as a universal solvent, ethanol remained unable to draw EPA and DHA, which are non-polar, from the body of sea cucumbers. ${ }^{3}$

Quicker healing occurred in treatment group with extracted ethanol of sea cucumbers compared to $\mathrm{K}$ and $\mathrm{AH}$ groups since sea cucumber contains various compounds which function in wound healing, such as protein and glycosaminoglycans (GAGs) which comprises chondroitine sulphate, hyaluronic acid, dermatan sulphate, and hepharane sulphate. Those substances are inter-related in the phase of wound healing and thus it plays an important role in repairing tissue. ${ }^{5,6}$ The contents of chondroitine sulphate, hyaluronic acid, dermatan sulphateand hepharane sulphate in extracted ethanol of sea cucumber are respectively $1.168 \%$, $0.693 \%, 0.635 \%$, and $0.196 \%$. In addition, the percentage of hyaluronic acid content in extracted ethanol is also bigger compared to the $\mathrm{AH}$ group.
Protein is very important in body tissue maintenance and repair. The low protein within the body will inhibit wound healing through fibroblast proliferation, proteoglycan (PG) synthesis and collagen, while an adequate amount of protein causes wound healing to occur quickly or optimally. ${ }^{22}$

Out of $19.39 \%$ of the protein contained in the extracted ethanol of sea cucumbers, about $80 \%$ constitutes collagen. ${ }^{23}$ In hemostasis and inflammation phase, the collagen takes part in assisting the hemostasis process, withdrawing macrophages with chemotaxis ability, and causing natural cleaning of inflammation infiltrate. In proliferation phase, the collagen act as a fold to combine fibroblast, withdraw fibroblast to the wound area and in the matrix structure it will become the model for the growth of new tissue, while in the maturation phase, the collagen gives the strength to the new tissues and improves specific collagen fibre organization in the phase of wound healing remodeling. ${ }^{24}$

In the research by Zou et al., ${ }^{25}$ concerning the application of chondroitin sulphate for palatal mucosa of the oral cavity, the research results show the increasing migration, adhesion, proliferation of palatal fibroblast cells and wound covering, while in the process of inflammation, the chondroitin sulphate may reduce the inflammation reaction (necro-inflammation) which prevents worse cell destruction. ${ }^{25,26}$ Hyaluronic acid influences the speed of cell migration in the process of the wound covering, inflammation, re-epithelization and cells proliferation. ${ }^{27}$ Dermatan sulphate plays a role in the phases of proliferation and maturation. In the research performed by Penc et al., in Trowbridge and Gallo ${ }^{28}$, dermatan sulphate can support the ability of FGF-2 to give the signal of cells proliferation. Hepharane sulphate and hepharine play roles in angiogenesis in the proliferation phase. 
Hepharane sulphate in the surface of cells and the extracellular environment is crucial for a physiological process including angiogenesis or the growth of new blood vessel, in which hepharane sulphate deeply impacts bioactivation of angiogenic key factors, i.e. VEGF. ${ }^{29}$ In addition, hepharane sulphate is also recognized for its contribution in the process of cells growth, migration and differentiation. ${ }^{30}$

SH60 and SH80 groups did not show any significant difference, though it is described that both groups have different diameter difference in which in SH60 group the diameter difference is quite bigger than in $\mathrm{SH} 80$. It is probably because Stichopus hermanni contains sea cucumber's triterphenoyde glycoside against namely Triterpene glycoside, which is assumed to be able to impede the wound healing. Triterpene Glycoside in the family of Holothuroidea shows high scientific value in pharmacology, including having anti-neoplastic nature. ${ }^{31}$ This is supported by the research conducted by Sari and Saleh ${ }^{10}$ reporting that the level of triterpene glycoside in the extracted ethanol of sea cucumber is $3.57 \% .^{10}$

\section{CONCLUSIONS}

In this research, it can be generally concluded that the sea cucumber (Stichopus hermanni) gel has the potency in oral cavity TU recovery, in which the extracted ethanol of Stichopus hermanni $60 \%$ has the potency to speed up the recovery of oral mucosa.

\section{ACKNOWLEDGEMENT}

This research was supported by The Grantin-Aid for Scientific from The Ministry of Research, Technology and Higher Education of the Republic of Indonesia 2013

\section{REFERENCES}

1. Nolan A, Baillie C, Badminton J, Rudralingham $\mathrm{M}$ and Seymour RA. The Efficacy of Topical Hyaluronic Acid in The Management of Recurrent Aphthous Ulceration. J Oral Pathol Med 2006;35(8):461-5.

2. Zohdi RM, Zakaria ZAB, Yusof N, Mustapha NM, Abdullah MNH. Sea Cucumber (Stichopus hermanni) Based Hydrogel to Treat Burn Wounds in Rats. Wiley Periodicals 2011;98B(1).

3. Bordbar S, Anwar F, Saari N. High-Value Components and Bioactives from Sea Cucumbers for Functional Foods-A Review. Mar Drugs. 2011;9(10):1761-805.

4. Sari RP. Modulasi FGF2 setelah pemberian aplikasi topikal gel Stichopus hermanni pada ulkus traumatikus tikus Wistar. Dent. J. (Maj. Ked. Gigi). September 2014;47(3):126-9.

5. Soepribadi. Regenerasi dan penyembuhan untuk kedokteran gigi. CV. Sagung Seto 2013:p.57,71-6.

6. Pardue EL, Ibrahim S, Ramamurthi. Role of hyaluronan in angiogenesis and its utility to angiogenic tissue Engineering. Organogenesis 2008; 4(4):203-14.

7. Collins N, Sulewski C. Omega-3 fatty acids and wound healing. Ostomy Wound Management. 2011:10-3.

8. McDaniel JC, Belury $\mathrm{M}$, Ahijevych $\mathrm{K}$ dan Blakely W. w-3 Fatty Acids Effect on Wound Healing. Wound Repair Regen, 2008;16(3): 337-45.

9. Underwood, A.L. and R. A. Day, Jr. Analisis Kimia Kuantitatif, a.b.: Pudjaatmaka, A.H., Edisi Kelima, Erlangga, Jakarta 2002;421-8.

10. Ridzwan BH, Leong TC, Idid SZ. The antinociceptive of water extract from sea cucumbers Holothuria leucospilota Brandt, Bohadschia marmorata vitiensis Jaeger and Coelomic fluid from Stichopus hermanii. Pakistan Journal of Biological Sciences, 2003; 6 (24) : 2068-2072

11. Sari RP, Saleh MR. The Comparison of Triterpene Glycoside Level with Various Extract Solvent Methods for Preparing Stichopus Hermanni Gel. Proceeding Book $8^{\text {th }}$ International Dental Scientific Meeting, Makasar 2014;85-90.

12. Albuntana, Arum, Yasman, dan Wisnu Wardhana. Uji Toksisitas Ekstrak Empat Jenis Teripang Suku Holothuriidae Dari Pulau Penjaliran Timur, Kepulauan Seribu, Jakarta Menggunakan Brine Shrimp Lethality Test (BSLT), 2011; 3(1): 69-70.

13. Shojaei AH, Chang RK, Guo X, Burnside BA, Couch RA. Systemic drug delivery via the buccal mucosa route. Pharm Tech 2001;6:7081. 
14. Winarno, F.G. Kimia Pangan dan Gizi. Gramedia Pustaka Utama, Jakarta 2004.p.

15. Zhou SG, Jiao QC, Chen L, Liu Q. Binding interaction between chondroitin sulphatee and methylene blue by spectrophotometry. Spectroscopy Letters 2002;35(1):21-9.

16. AOAC. Official methods of analysis of the association of official analytical chemist. Vol IIA. AOAC International, Washington 1995;28.057.

17. Andreollo NA, Santos EF, Araujo MR and Lopes LR. Rat's Age Versus Human's Age: What is The Relationship?. ABCD Arq Bras Cir Dig. 2012;25(1):49-51.

18. Kusumawati D. Biologi Hewan Coba. Bersahabat Dengan Hewan Coba. Yogyakarta: Gajah Mada University Press 2004. P. 20-26

19. Ali ZH and Dahmoush HM. Propolis Versus Daktarin in Mucosal Wound Healing. Life Science Journal 2012;9(2):624-36.

20. Murhadi, Suharyono AS, Susilawati. Aktivitas Antibakteri Ekstrak Daun Salam (Syzygium polyanta) dan Daun Pandan (Pandanus amaryllifolius). Jurnal Teknologi dan Industri Pangan 2007;18(1):17-24.

21. Underwood, A.L. and R. A. Day, Jr. Analisis Kimia Kuantitatif, a.b.: Pudjaatmaka, A.H., Fifth Edition, Erlangga, Jakarta, 2002;421-8.

22. Guo $S$ and DiPietro LA. Factors Affecting Wound Healing. Journal of Dental Research 2010;89:219-29.

23. Arlyza I. Teripang dan Bahan Aktifnya. Oseana 2009;34(1):9-17.

24. Fitzgerald $\mathrm{RH}$ and Steinberg JS. Collagen in Wound Healing: Are We onto Something New or Just Repeating the Past? The Foot and Ankle Online Journal 2009;2(9):1-5.

25. Zou XH, Foong WC, Cao T, Bay BH, Ouyang HW, Yip GW. Chondroitin Sulphatee in Palatal Wound Healing. The Journal of Dental Research 2004;83(11):880-5.

26. Nurhidayati. Efek Protektif Teripang Pasir (Holothuria scabra) terhadap Hepatotoksistas yang Diinduksi Karbon Tetraklorida (CCl4). Tesis, Fakultas Kedokteran: Universitas Airlangga, Surabaya 2009. p. 75-80

27. Gomes JAP, Amankwah R, Powel-Richards A, Dua HS. Sodium Hyaluronate (Hyaluronic Acid) Promotes Migration of Human Corneal Epithelial Cells in Vitro. British Journal of Ophthalmology 2004;88:821-5.

28. Trowbridge $G$ and Gallo RL. Dermatan Sulphatee: New Functions from an Old Glycosaminoglycan. Glycobiology 2002; 12(9):117-25.

29. Stringer SE. The Role of Hepharane Sulphate Proteoglycans in Angiogenesis. Biochemical Society Transactions 2006;34(3):451-3.

30. Olczyk P., Komosinska-Vassev K., WinszSzczotka K., Kozma E. M., Wisowski G., Stojko J., et al. (2012). Propolis modulates vitronectin, laminin, and heparan sulfate/heparin expression during experimental burn healing. J. Zhejiang Univ. Sci. 2012;13(11):932-41.

31. Caulier G, Van Dyck S, Gerbaux P, Eeckhaut I, Flammang P. Review of saponin diversity in sea cucumbers belonging to the family Holothuriidae. SPC Beche-de-mer Information Bulletin 2011; (31): 48-54 